\title{
Mycoplasma sturni sp. nov., from the Conjunctiva of a European Starling (Sturnus vulgaris)
}

\author{
M. H. FORSYTH ${ }^{1}{ }^{\dagger}$ J. G. TULLY ${ }^{2}$ T. S. GORTON, ${ }^{1}$ L. HINCKLEY, ${ }^{1}$ S. FRASCA, JR., ${ }^{1,3}$ \\ H. J. VAN KRUININGEN, ${ }^{1,3}$ AND S. J. GEARY ${ }^{1 *}$ \\ Department of Pathobiology ${ }^{1}$ and the Northeastern Research Center for Wildlife Diseases, ${ }^{3}$ University of Connecticut, \\ Storrs, Connecticut 06269-3089, and Mycoplasma Section, National Institute of Allergy and Infectious Diseases, \\ Frederick Cancer Research and Development Center, Frederick, Maryland 21702-1201 ${ }^{2}$
}

\begin{abstract}
Strain $\mathrm{UCMF}^{\mathrm{T}}$ (T = type strain) was isolated from the conjunctiva of a European starling (Sturnus vulgaris) with conjunctivitis. Colonies grown on conventional mycoplasma agar possessed the typical fried-egg appearance observed with many mycoplasmal species. Electron micrographs of ultrathin sections of $U_{C M F}{ }^{\mathrm{T}}$ revealed a pleomorphic cellular morphology; the cells ranged from spherical to elliptical or flask shaped. The cell size ranged from 0.3 to $0.5 \mu \mathrm{m}$. Strain $\mathrm{UCMF}^{\mathrm{T}}$ grows well in a variety of mycoplasma broth formulations at $25^{\circ} \mathrm{C}$, with rapid and heavy growth at $37^{\circ} \mathrm{C}$. No growth occurs at $42^{\circ} \mathrm{C}$. This organism ferments glucose but does not

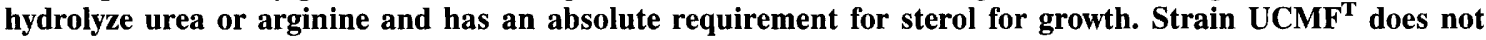
hemagglutinate or hemadsorb chicken erythrocytes. The genome size is $870 \mathrm{kbp}$, and the guanine-plus-cytosine content is $31 \mathrm{~mol} \%$. Sequence analysis of the $16 \mathrm{~S}$ rRNA gene demonstrated that this organism is unique and has not been described previously. Serological analysis confirmed that strain $\mathrm{UCMF}^{\mathrm{T}}$ is distinct from all previously identified Mycoplasma, Acholeplasma, Spiroplasma, Entomoplasma, and Mesoplasma species. This organism represents a new species, for which we propose the name Mycoplasma sturni. Strain UCMF (= ATCC 51945) is the type strain of $M$. sturni sp. nov.
\end{abstract}

Members of the class Mollicutes are prokaryotic organisms which are devoid of cell wall material. Although members of the genera Ureaplasma and Acholeplasma have been isolated from avian hosts, the majority of isolates belonging to the class Mollicutes are members of the genus Mycoplasma (10).

In this paper, we describe the isolation and characterization of a novel species of mycoplasma obtained from the conjunctiva of an adult European starling (Sturnus vulgaris) with conjunctivitis. This bird was submitted as part of an ongoing effort to monitor the incidence of conjunctivitis in house finches (Carpodacus mexicanus) and other passerines along the east coast of the United States. Although the new organism (strain $\mathrm{UCMF}^{\mathrm{T}}[\mathrm{T}=$ type strain]) was isolated in pure culture from a clinical case of naturally occurring conjunctivitis, its role as a primary pathogen of passerines has yet to be definitively established.

On the basis of the standards set forth for the description of new species of mycoplasmas (9), this organism is a distinct, previously undescribed mycoplasma species. We propose the name Mycoplasma sturni for this new species.

\section{MATERIALS AND METHODS}

Isolation. The new organism was isolated from a live European starling submitted to the Northeastern Research Center for Wildlife Diseases at the University of Connecticut. The bird had severe bilateral conjunctivitis with mucocaseous discharge. Moderate blepharitis was noted, and the upper and lower eyelids of the left eye were crusted closed

Swabs of the left and right conjunctival sacs were used to inoculate fortified commercial (FC) broth (11), incubated at $37^{\circ} \mathrm{C}$ for $48 \mathrm{~h}$, and then plated onto $\mathrm{FC}$ agar plates, which were incubated in a humidified environment at $37^{\circ} \mathrm{C}$ until colonies with the typical fried-egg morphology were evident. No other organism was isolated from the swabs.

Media and growth conditions. Strain $\mathrm{UCMF}^{\mathrm{T}}$ was isolated and subcultured in

* Corresponding author. Mailing address: Department of Pathobiology, U-89, 61 N. Eagleville Rd., University of Connecticut, Storrs, CT 06269-3089. Phone: (860) 486-0835. Fax: (860) 486-2794.

$\dagger$ Present address: Department of Medicine, Division of Infectious Diseases, Vanderbilt University, Nashville, TN 37232-2605.
FC broth and on FC agar. Later passages were also subcultured in avian mycoplasma medium SP-4 (10\% horse serum, $0.25 \mathrm{mg}$ of glucose per ml, Phenol Red Broth Base [Difco]) (20). Cultures were incubated routinely at $37^{\circ} \mathrm{C}$ unless indicated otherwise. Strain $\mathrm{UCMF}^{\mathrm{T}}$ was purified by conventional filter cloning techniques (18). The range of permissive temperatures was determined by incubating a clonal population in $\mathrm{FC}$ broth at $25,30,32,35,37$, and $42^{\circ} \mathrm{C}$ for a maximum of 5 days.

Morphological studies. For electron microscopic studies, the organism was either pelleted from a mid-log-phase broth culture or picked as an agar plug containing a colony grown from overnight incubation of an inoculated $\mathrm{FC}$ aga plate. Samples were fixed in $1.5 \%$ paraformaldehyde and $1.5 \%$ glutaraldehyde in $0.1 \mathrm{M}$ sodium cacodylate buffer containing $3 \mathrm{mM} \mathrm{MgCl}_{2}$ at $\mathrm{pH}$ 7.3. Samples were washed in $0.1 \mathrm{M}$ sodium cacodylate buffer $(\mathrm{pH} 7.3)$ and postfixed with $2 \%$ osmium tetroxide. Specimens were dehydrated by using an ascending gradient of ethanol and then propylene oxide. They were then embedded in a resin mixture containing Araldite 502 (Electron Microscopy Sciences, Fort Washington, $\mathrm{Pa}$.) and Epon 812 (Tousimis Research Corp., Rockville, Md.). Ultrathin sections were cut with an Ultratome V (LKB-Produkter AB, Stockholm, Sweden), double stained with lead citrate and uranyl acetate, and observed with a model 300 electron microscope (Philips International, Eindhoven, The Netherlands).

The morphology of strain UCMF ${ }^{\mathrm{T}}$ cultivated in SP-4 broth was also examined by dark-field microscopy at a magnification of $\times 1,250$. Strain $\mathrm{UCMF}^{\mathrm{T}}$ grown on $\mathrm{FC}$ agar at $37^{\circ} \mathrm{C}$ was observed with a stereomicroscope, and typical colonies were photographed.

Biological and biochemical studies. Strain $\mathrm{UCMF}^{\mathrm{T}}$ was serially passaged in broth culture numerous times and then plated onto solid agar, incubated, and examined for typical colony formation. The technique used to assess filtration characteristics has been described previously (18). The techniques used to assess carbohydrate fermentation and hydrolysis of arginine and urea have also been described previously (2). The hemadsorption and hemagglutination properties were determined as described previously (5).

Sterol requirement. Growth requirements for sterol were determined by the standard broth culture method $(13,19)$ and by a technique that was specific for determining the Tween 80 requirement (14)

Serological test. Antiserum to strain $\mathrm{UCMF}^{\mathrm{T}}$ was produced in a rabbit by a standard technique (17). Standard disc growth inhibition tests (3) were performed on agar plates with strain $\mathrm{UCMF}^{\mathrm{T}}$ and antisera to the following fermentative and non-arginine-hydrolyzing mollicutes: Mycoplasma agalactiae $\mathrm{PG}^{\mathrm{T}}{ }^{\mathrm{T}}$, Mycoplasma alvi Ilsley ${ }^{\mathrm{T}}$, Mycoplasma anatis $1340^{\mathrm{T}}$. Mycoplasma bovigenitalium PG11 $^{\mathrm{T}}$, Mycoplasma bovirhinis PG43 ${ }^{\mathrm{T}}$, Mycoplasma bovis $\mathrm{PG} 45^{\mathrm{T}}$, Mycoplasma

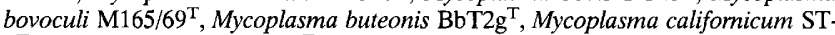
$6^{\mathrm{T}}$, Mycoplasma canis $\mathrm{PG}^{\mathrm{T}} \mathrm{T}^{\mathrm{T}}$, Mycoplasma capricolum subsp. capricolum Calif $\mathrm{Kid}^{\mathrm{T}}$, Mycoplasma capricolum subsp. capricolum $4330 \mathrm{Y}^{\mathrm{T}}$, Mycoplasma capricolum subsp. capripneumoniae $\mathrm{F} 38^{\mathrm{T}}$, Mycoplasma caviae $\mathrm{G} 122^{\mathrm{T}}$, Mycoplasma cavipharyngis $177 \mathrm{C}^{\mathrm{T}}$, Mycoplasma citelli $\mathrm{RG}-2 \mathrm{C}^{\mathrm{T}}$, Mycoplasma collis $58 \mathrm{~B}^{\mathrm{T}}$, Mycoplasma columborale MMP-4 ${ }^{\mathrm{T}}$, Mycoplasma conjunctivae HRC581 ${ }^{\mathrm{T}}$, Mycoplasma corogypsi $\mathrm{BV}^{\mathrm{T}}$, Mycoplasma cottewii $\mathrm{VIS}^{\mathrm{T}}$, Mycoplasma cricetuli $\mathrm{CH}^{\mathrm{T}}$, 


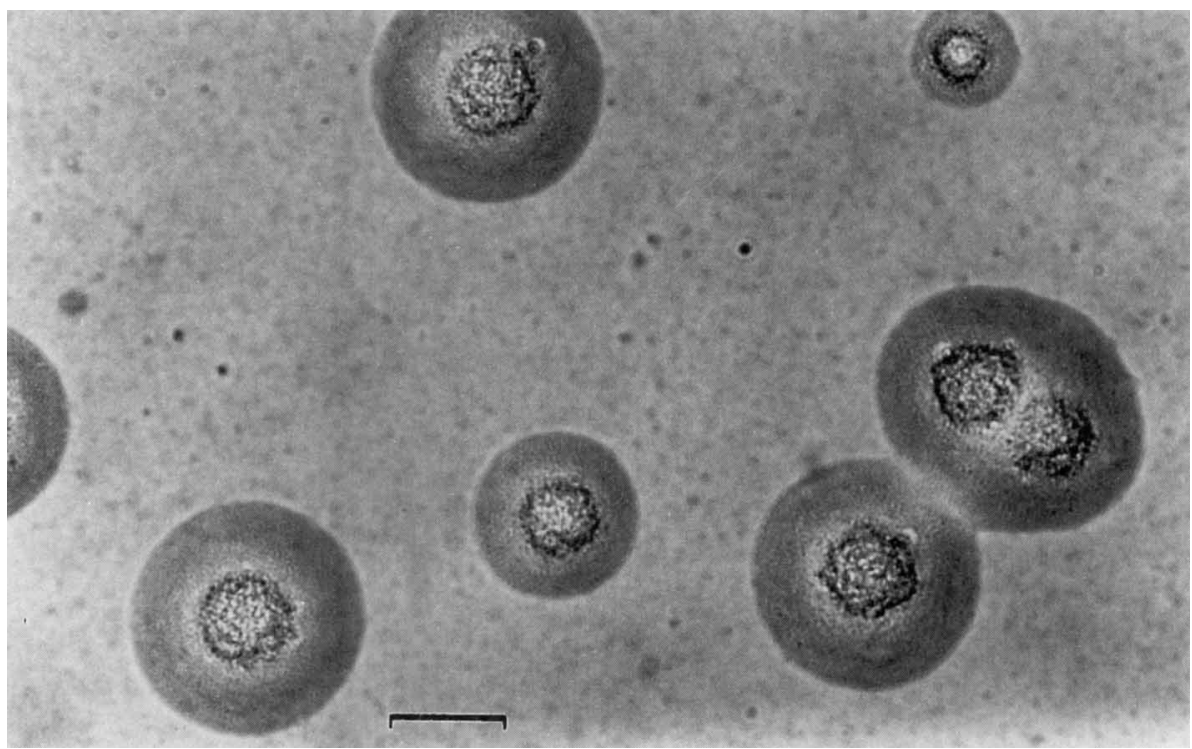

FIG. 1. Mycoplasma sturni colonies grown on $\mathrm{FC}$ agar. Bar $=100 \mu \mathrm{m}$.

Mycoplasma cynos $\mathrm{H831}{ }^{\mathrm{T}}$, Mycoplasma dispar $462 / 2^{\mathrm{T}}$, Mycoplasma edwardi PG24 ${ }^{\mathrm{T}}$, Mycoplasma equigenitalium $\mathrm{T} 37^{\mathrm{T}}$, Mycoplasma fastidiosum $4822^{\mathrm{T}}$, Mycoplasma feliminutum $\mathrm{Ben}^{\mathrm{T}}$, Mycoplasma felis $\mathrm{CO}^{\mathrm{T}}$, Mycoplasma fermentans $\mathrm{PG} 18^{\mathrm{T}}$, Mycoplasma flocculare Ms $42^{\mathrm{T}}$, Mycoplasma gallinaceum $\mathrm{DD}^{\mathrm{T}}$, Mycoplasma gallisepticum PG31 ${ }^{\mathrm{T}}$, Mycoplasma gallopavonis WR1 ${ }^{\mathrm{T}}$, Mycoplasma genitalium $\mathrm{G} 37^{\mathrm{T}}$, Mycoplasma glycophilum $486^{\mathrm{T}}$, Mycoplasma hyopneumoniae $\mathrm{J}^{\mathrm{T}}$ Mycoplasma hyorhinis BTS $7^{\mathrm{T}}$, Mycoplasma imitans $4229^{\mathrm{T}}$, Mycoplasma iowae 695 Mycoplasma iowae PPAV ${ }^{\mathrm{T}}$, Mycoplasma leocaptivus $3 \mathrm{~L} 2^{\mathrm{T}}$, Mycoplasma leopharyngis LL2 ${ }^{\mathrm{T}}$, Mycoplasma lipofaciens $\mathrm{R} 171^{\mathrm{T}}$, Mycoplasma moatsii $\mathrm{MK} 405^{\mathrm{T}}$, My coplasma mobile $163 \mathrm{~K}^{\mathrm{T}}$, Mycoplasma molare $\mathrm{H} 542^{\mathrm{T}}$, Mycoplasma mustelae MX ${ }^{\mathrm{T}}$, Mycoplasma mycoides subsp. mycoides $\mathrm{PG}^{\mathrm{T}}$, Mycoplasma mycoides subsp. mycoides UM30847, Mycoplasma mycoides subsp. capri $\mathrm{PG}^{\mathrm{T}}$, Mycoplasma neurolyticum Type $\mathrm{A}^{\mathrm{T}}$, Mycoplasma ovipneumoniae $\mathrm{Y}^{9} 8^{\mathrm{T}}$, Mycoplasma oxoniensis $128^{\mathrm{T}}$, Mycoplasma penetrans GTU54 ${ }^{\mathrm{T}}$, Mycoplasma phocarhinis $852^{\mathrm{T}}$, Mycoplasma pirum 70-159 ${ }^{\mathrm{T}}$, Mycoplasma pneumoniae $\mathrm{FH}^{\mathrm{T}}$, Mycoplasma pullorum $\mathrm{CKK}^{\mathrm{T}}$, Mycoplasma pulmonis $\mathrm{PG} 34^{\mathrm{T}}$, Mycoplasma putrefaciens $\mathrm{KS}-\mathrm{1}^{\mathrm{T}}$, Mycoplasma simbae $\mathrm{LX}^{\mathrm{T}}$, Mycoplasma sualvi Mayfield $\mathrm{B}^{\mathrm{T}}$, Mycoplasma synoviae $\mathrm{WVU}$ $1853^{\mathrm{T}}$, Mycoplasma testudinis $01008^{\mathrm{T}}$, Mycoplasma verecundum $107^{\mathrm{T}}$, Mycoplasma yeatsii $\mathrm{GIH}^{\mathrm{T}}$, Mycoplasma $\mathrm{sp}$. strains Calf 188, B5P, M7806, 3306, 3446, HRC689, and Utah C, Entomoplasma ellychniae ELCN-1 ${ }^{\mathrm{T}}$, Entomoplasma lucivorax PIPN-2 ${ }^{\mathrm{T}}$, Entomoplasma luminosum PIMN-1 ${ }^{\mathrm{T}}$, Entomoplasma melaleucae $\mathrm{M1}^{\mathrm{T}}$, Entomoplasma somnilux PYAN-1 ${ }^{\mathrm{T}}$, and Entomoplasma sp. strain BARC 318. In addition, agar colonies of strain $\mathrm{UCMF}^{\mathbf{T}}$ were also used in direct immunofluorescence tests (6) using individual fluorescein-conjugated antisera to each of the type strains listed above.

Genomic analysis. A preliminary genomic analysis of strain $\mathrm{UCMF}^{\mathrm{T}}$ was accomplished by means of arbitrary primer PCR as described previously (7). This initial screening was performed to differentiate the new organism from the commonly encountered avian mycoplasma isolates.

The genome size was determined by analyzing the sizes of DNA fragments following digestion of genomic DNA with the restriction endonuclease SmaI and field inversion gel electrophoresis as described previously (8)

The DNA base composition (guanine-plus-cytosine $[\mathrm{G}+\mathrm{C}]$ content) was determined on the basis the buoyant density of chromosomal DNA after ultracentrifugation in a $1.7-\mathrm{g} / \mathrm{ml}$ cesium chloride gradient (16). DNAs from Mycoplasma gallisepticum A5969 and Micrococcus lysodeikticus, whose $\mathrm{G}+\mathrm{C}$ contents were known, served as controls.

Cloning and DNA sequencing. The 16S rRNA gene was amplified from strain UCMF $^{\mathrm{T}}$ DNA by PCR utilizing Taq polymerase (Perkin-Elmer Cetus Corp., Norwalk, Conn.). The primers used were modifications of primers fD1 and rP1 (the $\mathrm{SalI}$ and $\mathrm{Bam} \mathrm{HI}$ sites were omitted from primers $\mathrm{ID} 1$ and $\mathrm{rP} 1$, respectively) (21) and were synthesized by the University of Connecticut Biotechnology Center. These primers have been used to amplify nucleotides 8 through 1512 of the $16 \mathrm{~S}$ rRNA gene of Escherichia coli, as well as a number of mycoplasma species (12). The PCR parameters used have been described previously (4). A PCR amplification product of the expected size was cloned into the PCR II TA vector (Invitrogen Corp., San Diego, Calif.) by using the manufacturer's suggested protocols. Plasmid DNA was maintained in $E$. coli $I N V \alpha F^{\prime}$ and was purified from alkaline lysates with Qiagen 100 columns (Qiagen, Inc., Chatsworth, Calif.). The sequences of both strands of the 16S rRNA gene were determined by the dideoxy chain termination method (15), using an Auto-Read DNA sequencing kit (Pharmacia Biotech., Inc., Piscataway, N.J.) and an automated laser fluorescence ALF DNA sequencer (Pharmacia). Homology searches were accomplished by using BLAST (1) and FASTA (GCG) with nonredundant nucleotide databases.

Nucleotide sequence accession number. The nucleotide sequence of the strain UCMF $^{\mathrm{T}}$ 16S rRNA gene determined in this study has been deposited in the GenBank database under accession number U22013.

\section{RESULTS AND DISCUSSION}

Isolation. Strain $\mathrm{UCMF}^{\mathrm{T}}$ was isolated in pure culture in $\mathrm{FC}$ medium without antibiotics from the eye of a European starling with bilateral conjunctivitis. It grew rapidly on agar with the fried-egg colony morphology which is characteristic of mycoplasmas (Fig. 1).

Growth and morphology. The new organism grew rapidly at various temperatures. Optimal growth appeared to occur at temperatures between 34 and $37^{\circ} \mathrm{C}$. Interestingly, it failed to grow in vitro at $42^{\circ} \mathrm{C}$, which is close to the normal avian body temperature. It was isolated from an eye, which, because of exposure to the environmental temperature and its thin membranous coatings, may have had a temperature below the core body temperature. Electron micrographs demonstrated that cell walls were absent and that membranes typical of members of the Mycoplasmatales were present (Fig. 2). They also showed that the cell size ranged from 0.3 to $0.5 \mu \mathrm{m}$. Log-phase broth cultures examined by either transmission electron or dark-field microscopy were homogeneous, and the cells were spherical. However, sections obtained by cutting through colonies grown on agar revealed more irregular flask-shaped and filamentous forms. The difference in cell morphology observed in the two growth matrices may have been due to different demands when the organism was growing in two different states (liquid phase and solid phase). No reversion to a walled bacterial form was observed after numerous passages in antibiotic-free broth or on agar plates.

Sterol requirement. Preliminary tests to determine the serum requirement for growth of strain $\mathrm{UCMF}^{\mathrm{T}}$ showed that the organism could be maintained through continuous passage through 23 serial dilutions in medium containing fetal bovine serum but that growth did not occur in a serum-free broth or 


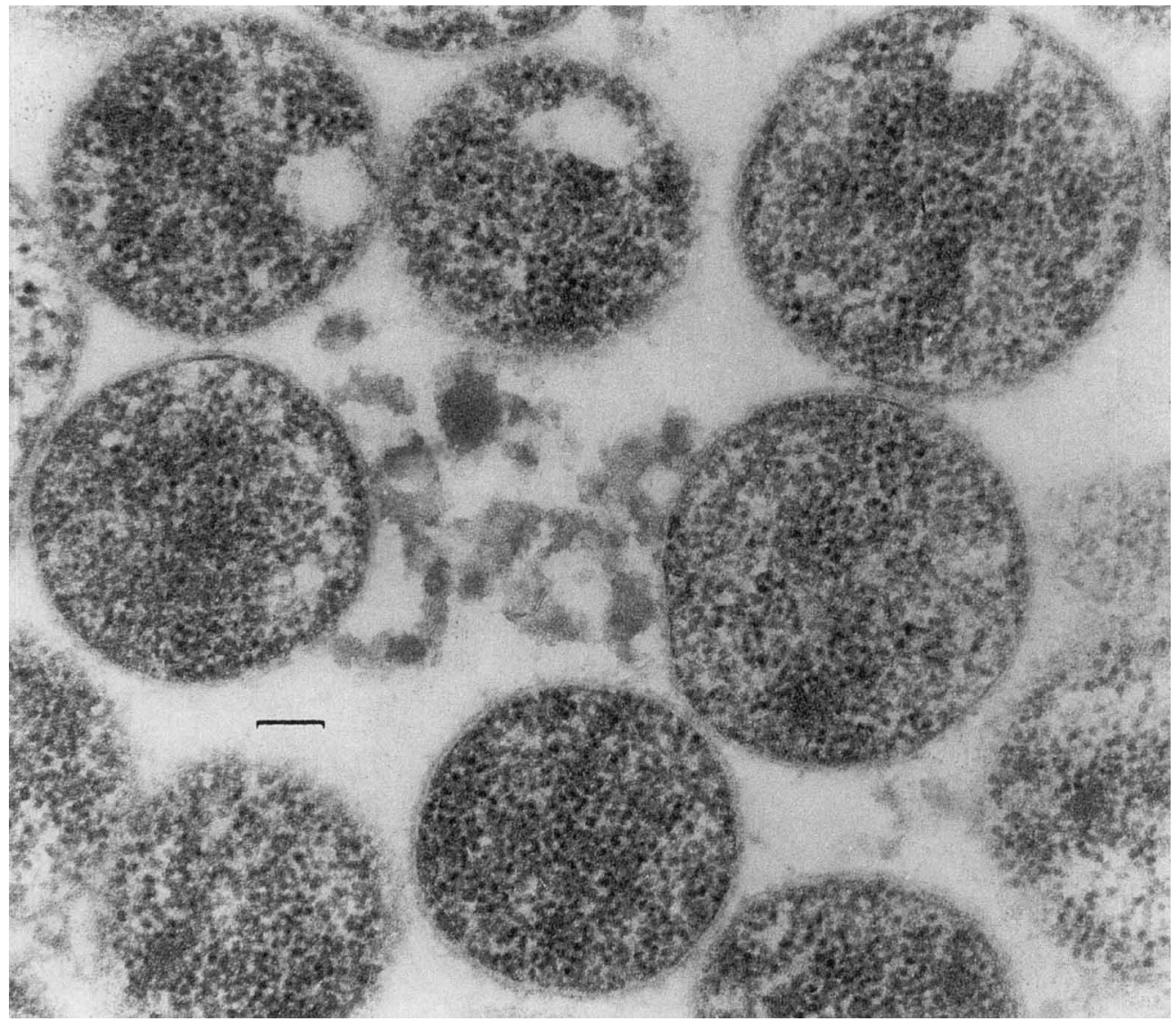

FIG. 2. Ultrathin section of a Mycoplasma stumi culture viewed and photographed with an electron microscope. Bar $=100 \mathrm{~nm}$.

in a serum-free medium supplemented with $0.04 \%$ polyoxyethylene sorbitan (Tween 80) (14). A standard cholesterol test, in which growth yields in various broth formulations were determined, indicated that the organism had a definite requirement for cholesterol (Table 1).

Biological and biochemical properties. Strain $U_{C M F}^{T}$ rapidly catabolized glucose but did not hydrolyze arginine or urea. This organism failed to bind chicken erythrocytes in both hemadsorption and hemagglutination tests. Unfiltered broth cultures typically had a titer of $10^{8}$ color-changing units $/ \mathrm{ml}$. Filtration through membranes with average pore diameters of

TABLE 1. Growth response of strain $\mathrm{UCMF}^{\mathrm{T}}$ to cholesterol

\begin{tabular}{lcc}
\hline $\begin{array}{c}\text { Supplement(s) added to serum-free } \\
\text { base medium }\end{array}$ & $\begin{array}{c}\text { Cholesterol } \\
\text { concn }(\mu \mathrm{g} / \mathrm{ml})\end{array}$ & $\begin{array}{c}\text { Amt of protein } \\
(\mathrm{mg} / 100 \mathrm{ml})^{a}\end{array}$ \\
\hline SP-4 medium & 0 (control) & 13.00 \\
$1 \%$ Bovine serum fraction medium & 0 (control) & 3.76 \\
None & 0 & $\mathrm{IG}^{b}$ \\
Albumin $(1 \%)$, Tween $80(0.01 \%)$, & 0 & $\mathrm{IG}$ \\
$\quad$ and palmitic acid $(10 \mu \mathrm{g} / \mathrm{ml})$ & 1 & 1.69 \\
& 5 & 2.40 \\
& 10 & 2.76 \\
& 20 & 2.83 \\
\hline
\end{tabular}

${ }^{a}$ Cellular protein yields from mycoplasmas sedimented from 100 -ml quantities of control broth or broth media containing various supplements. Each bottle received a $1 \%$ inoculum of strain $U_{C M F^{\mathbf{T}}}$ in bovine serum fraction broth, and cultures were harvested after 3 days of incubation at $37^{\circ} \mathrm{C}$.

${ }^{b} \mathrm{IG}$, insufficient growth.
450 and $300 \mathrm{~nm}$ also yielded titers of $10^{8}$ color-changing units/ $\mathrm{ml}$, while filtration through a 220 -nm-pore-diameter membrane filter yielded no viable organisms.

Serological tests. Growth inhibition tests performed with antisera to all previously recognized fermentative species in the genus Mycoplasma (see above) revealed that strain $\mathrm{UCMF}^{\mathrm{T}}$ was serologically distinct. These findings were confirmed by the results of direct agar plate immunofluorescence tests.

Genomic analysis. When BLAST and FASTA (GCG) were used, a search of the 16S rRNA nucleotide sequences in the GenBank databases did not reveal any sequence identical to the sequence determined for Mycoplasma sturni. However, on the basis of homology to various mycoplasmal 16S rRNA genes, it appears that Mycoplasma sturni belongs to the Mycoplasma hominis clade. An analysis of the 16S rRNA gene demonstrated that strain $\mathrm{UCMF}^{\mathbf{T}}$ is most closely related to Mycoplasma gallinaceum (level of homology, 93\%), Mycoplasma coragypsi (92.1\%), Mycoplasma felis (92\%), and Mycoplasma synoviae (91\%).

The pattern of bands resulting from arbitrary primer PCR amplification was distinct from the patterns obtained for the other mycoplasmas examined.

As determined by pulsed-field gel electrophoresis, the average total genome size of strain $\mathrm{UCMF}^{\mathrm{T}}$ was $870 \mathrm{kbp}$. The $\mathrm{G}+\mathrm{C}$ base composition was $31 \mathrm{~mol} \%$. This value was based on the values obtained for the two reference organisms, Mycoplasma gallisepticum and Micrococcus lysodeikticus, which were consistent with values determined previously ( 36 and $72 \mathrm{~mol} \%$, respectively). 
The properties of strain $\mathrm{UCMF}^{\mathrm{T}}$ described in this paper fulfill the criteria for species descriptions of members of the class Mollicutes (9). This organism does not have a cell wall, is filterable, fails to revert to walled bacteria when it is grown in the absence of antibiotics, is resistant to penicillin, and produces typical fried-egg colonies on agar. A growth requirement for serum or cholesterol, an optimum growth temperature of $37^{\circ} \mathrm{C}$, and a genome size of $870 \mathrm{kbp}$ place this organism in the order Mycoplasmatales. The inability of strain $\mathrm{UCMF}^{\mathrm{T}}$ to hydrolyze urea indicates that it belongs in the genus Mycoplasma. The lack of serological relatedness to previously described fermentative mycoplasma species indicates that this organism represents a new Mycoplasma species. We propose the name Mycoplasma sturni for strain $\mathrm{UCMF}^{\mathrm{T}}$.

The taxonomic description below summarizes the properties of the new species.

Description of Mycoplasma sturni sp. nov. Mycoplasma sturni (stur'ni. M. L. n. Sturnus, a genus of birds; M. L. gen. n. sturni, of the genus Sturnus, the genus of the bird from which the organism was isolated). Most cells are coccoid and have sizes ranging from 300 to $500 \mathrm{~nm}$, but some irregular flask-shaped and filamentous forms also occur. All cells lack a cell wall. Colonies on solid medium usually have a fried-egg appearance. Chemoorganotroph. Grows rapidly in broth medium, with acid production from glucose. Does not hydrolyze arginine or urea.

Cholesterol or serum is required for growth.

The optimum temperature for growth is 34 to $37^{\circ} \mathrm{C}$, and growth does not occur at $42^{\circ} \mathrm{C}$.

Serologically distinct from previously described Mycoplasma species.

Isolated from ocular tissues of a starling ( $S$. vulgaris) with conjunctivitis, but it has not been determined whether the organism plays a pathogenic role in avian disease.

The $\mathrm{G}+\mathrm{C}$ content of the DNA is $31 \mathrm{~mol} \%$, and the genome size, as determined by pulsed-field gel electrophoresis, is 870 kbp.

The type strain is strain UCMF (= ATCC 51945).

\section{ACKNOWLEDGMENTS}

This research was supported in part by grant CONSOO640 from the USDA Agricultural Experiment Station (to S.J.G.).

We thank Jenny Dickson for submitting the starling from which strain $\mathrm{UCMF}^{\mathrm{T}}$ was isolated, Lamia Khairallah for assisting with the electron microscopy, Emory Braswell for assisting with the $\mathrm{G}+\mathrm{C}$ content determination, and the University of Connecticut Biotechnology Center for synthesizing the oligonucleotide primers.

\section{REFERENCES}

1. Altschul, S. F., W. Gish, W. Miller, E. M. Myers, and D. J. Lipman. 1990 Basic local alignment search tool. J. Mol. Biol. 215:403-410.

2. Aluotto, B. B., R. G. Wittler, C. O. Williams, and J. E. Faber. 1970. Standardized bacteriologic techniques for characterization of Mycoplasma species. Int. J. Syst. Bacteriol. 20:35-58.

3. Clyde, W. A., Jr. 1983. Growth inhibition tests. Methods Mycoplasmol. 1:405-410.

4. Dybvig, K., and A. Woodard. 1992. Cloning and DNA sequence of a mycoplasmal recA gene. J. Bacteriol. 174:778-784.

5. Forsyth, M. H., M. E. Tourtellotte, and S. J. Geary. 1992. Localization of an immunodominant $64 \mathrm{kDa}$ lipoprotein (LP64) in the membrane of $\mathrm{Myco}$ plasma gallisepticum and its role in cytadherence. Mol. Microbiol. 6:20992196.

6. Gardella, R. S., R. A. Del Giudice, and J. G. Tully. 1983. Immunofluorescence. Methods Mycoplasmol. 1:431-439.

7. Geary, S. J., M. H. Forsyth, S. A. Saoud, G. Wang, D. E. Berg, and C. M. Berg. 1994. Mycoplasma gallisepticum strain differentiation by arbitrary primer PCR (RAPD) fingerprinting. Mol. Cell. Probes 8:311-316.

8. Gorton, T. S., M. S. Goh, and S. J. Geary. 1995. Physical mapping of the Mycoplasma gallisepticum S6 genome with localization of selected genes. J. Bacteriol. 177:259-263.

9. International Committee on Systematic Bacteriology Subcommittee on the Taxonomy of Mollicutes. 1995. Revised minimum standards for description of new species of the class Mollicutes (division Tenericutes) Int. J. Syst. Bacteriol. 45:605-612.

10. Jordan, F. T. W. 1979. Avian mycoplasmas, p. 1-48. In J. G. Tully and R. F. Whitcomb (ed.), The mycoplasmas, vol. 2. Academic Press, New York.

11. Macy, M. L. 1980. Tests for mycoplasmal contamination of cultured cells as applied at the ATCC. Tissue Culture Assoc. Manual 5:1151-1155.

12. Panagala, V. S., J. S. Stringfellow, K. Dybvig, A. Woodard, F. Sun, D. L. Rose, and M. M. Greshan. 1993. Mycoplasma corogypsi sp. nov., a new species from the footpad abscess of a black vulture, Coragyps atratus. Int. J. Syst. Bacteriol. 43:585-590.

13. Razin, S., and J. G. Tully. 1970. Cholesterol requirement of mycoplasmas. J. Bacteriol. 102:306-310.

14. Rose, D. L., J. G. Tully, J. M. Bove, and R. F. Whitcomb. 1993. A test for measuring growth responses of mollicutes to serum and polyoxyethylene sorbitan. Int. J. Syst. Bacteriol. 43:527-532.

15. Sanger, F., S. Nicklen, and A. R. Coulson. 1977. DNA sequencing with chain-terminating inhibitors. Proc. Natl. Acad. Sci. USA 74:5463-5467.

16. Schildkraut, C. L., J. Marmur, and P. Doty. 1962. Determination of the base composition of deoxyribonucleic acid from its bouyant density in $\mathrm{CsCl}$. J. Mol. Biol. 4:430-443.

17. Senterfit, L. B. 1983. Preparation of antigens and antisera. Methods Mycoplasmol. 1:401-404.

18. Tully, J. G. 1983. Cloning and filtration techniques for mycoplasmas. Methods Mycoplasmol. 1:173-177.

19. Tully, J. G. 1983. Tests for digitonin sensitivity and sterol requirement. Methods Mycoplasmol. 1:355-362.

20. Tully, J. G., D. L. Rose, R. F. Whitcomb, and R. P. Wenzel. 1979. Enhanced isolation of Mycoplasma pneumoniae from throat washings with a newly modified culture medium. J. Infect. Dis. 139:478-482.

21. Weisburg, W. G., S. Barns, D. A. Pelletier, and D. J. Lane. 1991. 16S ribosomal DNA amplification for phylogenic study. J. Bacteriol. 173:697703. 